\title{
In Memoriam: Muhsin S. Mahdi
}

Muhsin S. Mahdi, James Richard Jewett Emeritus Professor of Arabic at Harvard University, died on July 9 in Brookline, Massachusetts, after a protracted illness.

Professor Mahdi was born June 21, 1926 in Kerbala, Iraq. Following early studies there, he finished secondary school in Baghdad and then received a government scholarship to the American University in Beirut. A year later, he was sent to study economics at the University of Chicago.

There, his encounter with Arnold Bergsträsser, Yves Simon, Nabia Abbott, and Leo Strauss led to economics being replaced by philosophy. Mahdi finished his Ph.D. in 1954, and his dissertation was published as "Ibn Khaldun's Philosophy of History: A Study in the Philosophical Foundation of the Science of Culture." After an interlude at the University of Freiburg im Breisgau and at the University of Baghdad, he returned to the University of Chicago in 1957. There he remained until being appointed the James Richard Jewett Professor of Arabic at Harvard University in 1969, a position he held until his retirement in 1996.

Professor Mahdi conducted postdoctoral study at universities in the United States, Europe, North Africa, and the Middle East. He was the founding member of the Société Internationale pour l'Histoire des Sciences et de la Philosophie Arabes et Islamiques (SIHSPAI) and of the Middle East Studies Association, served on the editorial boards of several learned journals, was an officer in numerous other learned societies, and became the first corresponding member of the Cairo Academy of Arabic Language.

Thoroughly versed in ancient Greek, medieval Jewish and Christian, as well as modern Western philosophy, Muhsin Mahdi acquired an incomparable command of the Arabic language in its many historical and geographical manifestations. He grounded himself in the methods of critical editions of manuscripts developed by European scholars and formulated equally rigorous standards for Arabic and Islamic philosophy. He is especially known for the recovery, edition, translation, and interpretation of many of Alfarabi's writings. His 2001 Alfarabi and the Foundation of Islamic Political Philosophy brings together his deepest thinking on Alfarabi.

A demanding and inspiring teacher, Mahdi emphasized meticulous analysis and interpretation of philosophical texts in Arabic. Several of his students honored him in 1992 with the collection of essays, The Political Aspects of Islamic Philosophy. With Ralph Lerner and the late Fr. Ernest Fortin, he 
co-edited Medieval Political Philosophy: A Sourcebook, containing selections in translation from Arabic, Hebrew, and Latin. He is famous for his critical edition of the 1001 Nights, demonstrating that they consist only of 282 nights, and painstakingly explaining how 18th and 19th century Orientalist scholars falsely expanded the collection.

Charles E. Butterworth University of Maryland 